\title{
Horizontal effect of the surgical weakening of the oblique muscles
}

Efeito horizontal do debilitamento cirúrgico dos músculos oblíquos

Carlos Souza-Dias

Dear Editor

I ask you the kindness of correcting a mistake in my article that was published in the last number of the Arquivos Brasileiros de Oftalmologia. 2011;74(3):181-182

In the tables 1 and 2 (pages 181 and 182), in the bottom lines, there are the values of $p$. Please correct:
Table $1: p=1.6$ to $p=0.000000016 ; p=1.36$ to $p=0.000136 ; p=1.46$ to $p=0.00000146$

Table 2: $p=1.32$ to $p=0.0000132 ; p=1.37$ to $p=0.000137 ; p=1.44$ to $p=0.00044$

Thank you. 